\title{
Intake of Fish and Marine n-3 Polyunsaturated Fatty Acids and Risk of Cardiovascular Disease Mortality: A Meta-Analysis of Prospective Cohort Studies
}

\author{
Lan Jiang, Jinyu Wang, Ke Xiong, Lei Xu, Bo Zhang and Aiguo Ma *
}

Citation: Jiang, L.; Wang, J.; Xiong, K.; Xu, L.; Zhang, B.; Ma, A. Intake of Fish and Marine n-3 Polyunsaturated Fatty Acids and Risk of Cardiovascular Disease Mortality: A Meta-Analysis of Prospective Cohort Studies. Nutrients 2021, 13, 2342. https://doi.org/10.3390/nu13072342

Academic Editor: Hayato Tada

Received: 21 May 2021

Accepted: 4 July 2021

Published: 9 July 2021

Publisher's Note: MDPI stays neutral with regard to jurisdictional claims in published maps and institutional affiliations.

Copyright: (c) 2021 by the authors. Licensee MDPI, Basel, Switzerland. This article is an open access article distributed under the terms and conditions of the Creative Commons Attribution (CC BY) license (https:// creativecommons.org/licenses/by/ $4.0 /)$.
Institute of Nutrition and Health, School of Public Health, Qingdao University, Qingdao 266071, China; jiang159@163.com (L.J.); wangjinyu@qdu.edu.cn (J.W.); kexiong@qdu.edu.cn (K.X.); xulei951121@163.com (L.X.); zhangzhang19940516@163.com (B.Z.)

* Correspondence: magfood@qdu.edu.cn

\begin{abstract}
Previous epidemiological studies have investigated the association of fish and marine n-3 polyunsaturated fatty acids (n-3 PUFA) consumption with cardiovascular disease (CVD) mortality risk. However, the results were inconsistent. The purpose of this meta-analysis is to quantitatively evaluate the association between marine n-3 PUFA, fish and CVD mortality risk with prospective cohort studies. A systematic search was performed on PubMed, Web of Science, Embase and MEDLINE databases from the establishment of the database to May 2021. A total of 25 cohort studies were included with 2,027,512 participants and 103,734 CVD deaths. The results indicated that the fish consumption was inversely associated with the CVD mortality risk [relevant risk (RR) $=0.91 ; 95 \%$ confidence intervals (CI) 0.85-0.98]. The higher marine n-3 PUFA intake was associated with the reduced risk of CVD mortality ( $R R=0.87 ; 95 \%$ CI: 0.85-0.89). Dose-response analysis suggested that the risk of CVD mortality was decreased by $4 \%$ with an increase of $20 \mathrm{~g}$ of fish intake (RR $=0.96 ; 95 \%$ CI: 0.94-0.99) or 80 milligrams of marine $n-3$ PUFA intake (RR $=0.96$; $95 \%$ CI: $0.94-0.98$ ) per day. The current work provides evidence that the intake of fish and marine n-3 PUFA are inversely associated with the risk of CVD mortality.
\end{abstract}

Keywords: fish; n-3 polyunsaturated fatty acid; cardiovascular disease mortality; meta-analysis; prospective cohort studies

\section{Introduction}

Cardiovascular diseases (CVD) are a group of disorders of the heart and blood vessels, including coronary heart disease, cerebrovascular disease, rheumatic heart disease and other conditions. The global CVD mortality increased 12.5\% from 2005 to 2015. 17.9 million people died of CVD in 2015 [1]. In addition to drug treatment, the potential role of dietary components hasreceived increased attention. Previous studies have shown the effectiveness of healthy dietary patterns and components for the prevention of CVD and other diseases [2-4]. Fish is rich in various nutrients (e.g., protein, vitamin D and polyunsaturated fatty acids) and may have a beneficial role in preventing CVD events [5,6].

Marine n-3 polyunsaturated fatty acids (n-3 PUFA) - including eicosapentaenoic acid (EPA), docosahexaenoic acid (DHA) and docosapentaenoic acid (DPA) — mainly exist in fatty fish. A high consumption of n-3 PUFA from fatty fish led to an increase in highdensity lipoprotein and a decrease in inflammation factors [7,8]. Besides, n-3 PUFA may improve heart rate and blood pressure through improving left ventricular diastolic filling or augmenting vagal tone [9].

Previous epidemiological studies have investigated the association of fish consumption with CVD mortality risk $[10,11]$. A recent meta-analysis of prospective observational studies revealed a negative association between fish intake and CVD mortality risk [12]. In recent years, another 11 prospective cohort studies investigated the association between 
fish intake and CVD mortality risk, but the findings were inconsistent [13-16]. The EPICNetherlands cohort study suggested that fish was not associated with the risk of CVD mortality [17]. In contrast, the NIH-AARP Diet and Health Study found that fish had a protective effect on CVD mortality risk [18]. To our knowledge, there has been no metaanalysis of prospective observational studies for investigating the association of marine n-3 PUFA consumption with CVD mortality risk. Therefore, we conducted this meta-analysis to comprehensively investigate the associations between fish, marine n-3 PUFA intake and CVD mortality risk. Furthermore, dose-response analyses were conducted to quantify the associations.

\section{Materials and Methods}

\subsection{Data Sources and Search Strategy}

Systematic search was performed on PubMed, Web of Science, Embase and MEDLINE from the establishment to May 2021. The search was limited to English literature, and the search keywords were "fish", "seafood", "fish products", "fish oil", "EPA", "eicosapentaenoic acid", "DHA", "docosahexaenoic acid", "DPA", "docosapentaenoic acid", "n-3 polyunsaturated fatty acid", " $\omega-3$ polyunsaturated fatty acid", "n-3 PUFA", " $\omega-3$ PUFA", "cardiovascular diseases", "CVD", "cardiovascular", "cohort", "follow-up", "prospective" and "longitudinal".

\subsection{Study Selection}

Two project members (L.J. and B.Z.) independently screened all titles and abstracts of the retrieved studies. Disagreements regarding the inclusion of the studies and the interpretation of the data were resolved by discussion among investigators. The studies were included in this meta-analysis if they met the following criteria: (1) study design: prospective cohort studies; (2) exposure: fish and marine n-3 PUFA; (3) source of n-3 PUFA: marine-derived n-3 PUFA (DHA, DPA, and EPA); and (4) outcomes: total CVD mortality which was reported as multivariate-adjusted relative risk (RR) and $95 \%$ confidence intervals (CI). The studies were excluded with the following criteria: (1) irrelevant; (2) not human studies; (3) not cohort studies; (4) not English studies.

\subsection{Data Extraction}

The following information was extracted from each eligible study: first author's surname; the year of publication; country; age; follow-up duration; the number of CVD deaths, sample size; gender; exposure levels; multivariate-adjusted RR with $95 \% \mathrm{CI}$ for the highest versus the lowest category of fish or marine n-3 PUFA intake; adjusted covariates. Consumption of fish and marine n-3 PUFA was collected with adjusted RR ( $95 \% \mathrm{CI})$ to conduct dose-response analyses. Newcastle-Ottawa Quality Assessment Scale (NOS) was adopted to evaluate the quality of each included study [19]. The NOS score ranges from 0 (bad) to 9 (good).

The quality evaluation was performed independently by two project members (L.J. and B.Z.). The NOS quality score system assessed 3 items: population selection, comparability of the groups and outcome assessment. Any discrepancies in grading the quality were addressed by group discussion.

\subsection{Statistical Analyses}

All statistical analyses were performed using Stata (Version 15.1). RRs with 95\% CI for all the exposure categories were extracted for the analysis. The main effect was RRs with $95 \%$ CI. A two-tailed $p<0.05$ was considered as statistically significant. The summary estimation was conducted through the comparison of the highest and the lowest category. Heterogeneity was assessed using the $\mathrm{I}^{2}$ statistic. In the case of heterogeneity for $\mathrm{I}^{2}>50 \%$, a random-effect model was adopted to pool the results. Otherwise, a fixed effect model was chosen. 
Sensitivity analysis was implemented by deleting one study at a time. Subgroup analyses and meta-regression were performed to identify the possible sources of heterogeneity. In the subgroup analyses, the included studies were stratified by location (Asia, Europe plus America, Oceania and Five Continents), follow-up duration ( $<9$ and $\geq 9$ years), etc. In meta-regression, gender, country, dropout rate, follow-up duration, CVD history, adjustment for diabetes and adjustment for smoking were used as the covariates. Potential publication bias was accessed using funnel plots and Egger's test $(p<0.1$ was considered statistically significant).

Non-linear dose-response analyses were performed to evaluate the relationship between fish, marine n-3 PUFA intake and CVD mortality risk [20]. Potential non-linear correlation was accessed by modeling the consumption level using restricted cubic splines. The distribution of four fixed knots were $5 \%, 35 \%, 65 \%$ and $95 \%$ [21]. Owing to the discrepancy of fish and marine n-3 PUFA intake categories, we selected studies with clear doses to perform dose-response analyses. Among each study, we used the median or mean consumption of fish and marine n-3 PUFA from each category. For open-ended categories, we set the lower boundary to zero in lowest category and the width of the category to be the same as the adjacent interval in the highest one $[12,22]$.

\section{Results}

\subsection{Literature Search and Study Characteristics}

The process of literature search is presented in Figure 1. A total of 11,120 articles were identified. After screening the title and abstract, forty-five studies were selected for full-text evaluation. By full-text examination, twenty-five articles were eventually included for data synthesis with 2,027,512 participants and 103,734 CVD deaths [11,13-18,23-40].

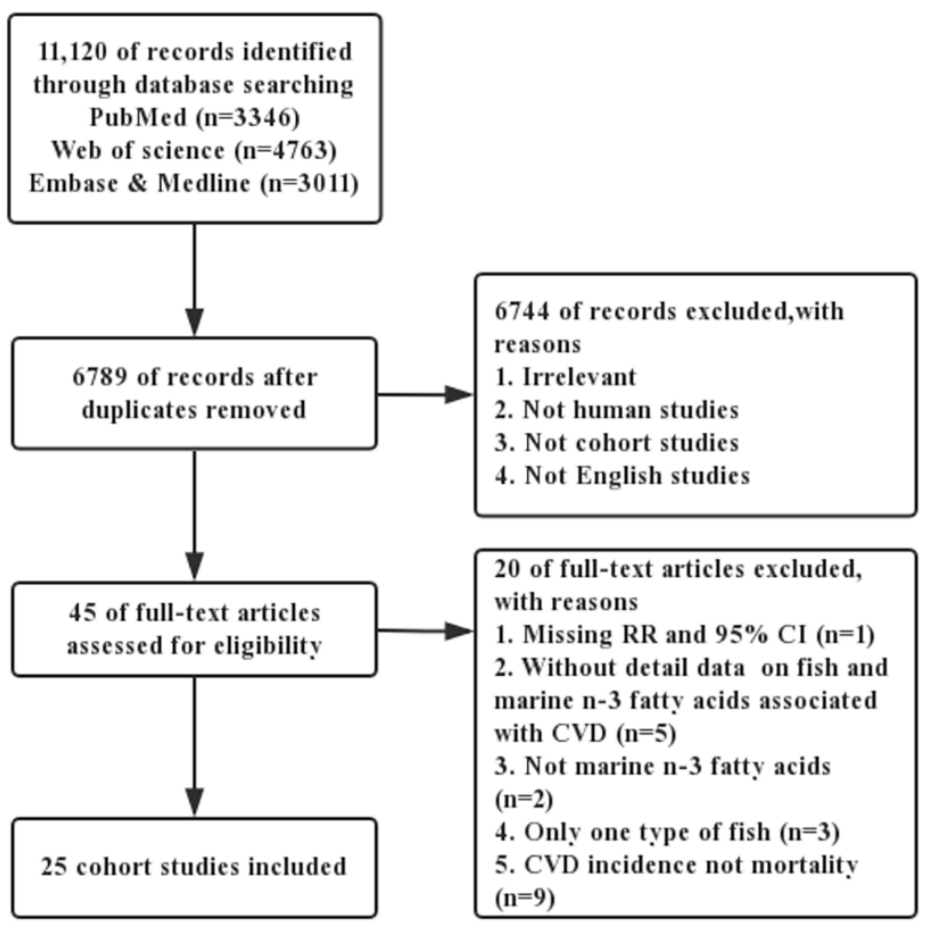

Figure 1. The flowchart for detailed steps of literature search.

The characteristics of the included studies are shown in Tables 1 and 2. Among these articles, sixteen were from Europe and America, seven from Asia, one from Oceania and one from five continents. The range of the age was $18-84$ years old. The population in the study included males and females. Besides, follow-up duration ranged from 5-30 years and the NOS quality score ranged from 6-9 points (Tables S1 and S2). 
Table 1. General characteristics of the studies included in meta-analysis of fish intake and risk of CVD mortality.

\begin{tabular}{|c|c|c|c|c|c|c|c|c|}
\hline $\begin{array}{l}\text { Author Name, Year, } \\
\text { Country }\end{array}$ & $\begin{array}{l}\text { Age } \\
\text { Range/Mean } \\
\text { Age (y) }\end{array}$ & $\begin{array}{l}\text { Follow-Up } \\
\text { Duration }\end{array}$ & $\begin{array}{l}\text { Number of } \\
\text { Cases/Size }\end{array}$ & Gender & Quantile & $\begin{array}{l}\text { Adjusted RR } \\
\quad(95 \% \mathrm{CI})\end{array}$ & $\begin{array}{l}\text { Quality } \\
\text { Score }\end{array}$ & Adjustments \\
\hline $\begin{array}{l}\text { Mohan 2021, Asia, Africa, } \\
\text { America, Europe and } \\
\text { Oceania [40] }\end{array}$ & 54.1 & 7.5 & $6502 / 191,454$ & $\mathrm{M} / \mathrm{F}$ & 4 & $\begin{array}{c}0.85 \\
(0.77-0.94)\end{array}$ & 6 & $\begin{array}{l}\text { Age, sex, study center, BMI, educational level, smoking status, } \\
\text { alcohol intake, physical activity, urban or rural location, history of } \\
\text { diabetes, cancer, use of statin or antihypertension medications, and } \\
\text { intake of fruit, vegetables, red meat, poultry, dairy, and total energy }\end{array}$ \\
\hline Kobayashi 2019, Japan [13] & $45-74$ & 14.9 & $2942 / 79,904$ & $\mathrm{M} / \mathrm{F}$ & 5 & $1.14(0.99-1.32)$ & 9 & $\begin{array}{l}\text { Age, area, BMI, alcohol intake total energy intake, coffee intake, } \\
\text { green tea intake, smoking status, physical activity, occupation type, } \\
\text { solitude and other food group }\end{array}$ \\
\hline Kondo 2019, Japan [15] & $30-79$ & 29 & $1070 / 9115$ & $\mathrm{M} / \mathrm{F}$ & 3 & $\begin{array}{c}0.72 \\
(0.57-0.91)\end{array}$ & 8 & Age, sex, smoking status, drinking status, and total energy intake \\
\hline $\begin{array}{l}\text { Van den brandt 2019, The } \\
\text { Netherlands [16] }\end{array}$ & $55-69$ & 10 & $2985 / 120,852$ & $\mathrm{M} / \mathrm{F}$ & 4 & $\begin{array}{c}1.45 \\
(1.20-1.74)\end{array}$ & 9 & $\begin{array}{l}\text { Age at baseline, sex, cigarette smoking status, number of cigarettes } \\
\text { smoked per day, years of smoking, diabetes, body height, } \\
\text { non-occupational physical activity, highest level of education, } \\
\text { intake of alcohol, vegetables and fruit, use of nutritional } \\
\text { supplements and, in women, postmenopausal HRT }\end{array}$ \\
\hline Deng 2018, USA [14] & $\geq 18$ & 18 & $326 / 1136$ & $\mathrm{M} / \mathrm{F}$ & 3 & $\begin{array}{c}0.69 \\
(0.50-0.96)\end{array}$ & 7 & $\begin{array}{l}\text { Age, sex, race/ethnicity, family income, the type of residential area, } \\
\text { cigarette smoking, alcohol drinking, and the history of } \\
\text { cardiovascular disease assessed at the baseline survey, and the } \\
\text { years of using insulin as the indicator of diabetes severity }\end{array}$ \\
\hline $\begin{array}{l}\text { Hengeveld 2018, The } \\
\text { Netherlands [17] }\end{array}$ & $20-70$ & 18 & $540 / 34,033$ & $\mathrm{M} / \mathrm{F}$ & 3 & $\begin{array}{c}0.94 \\
(0.80-1.10)\end{array}$ & 9 & $\begin{array}{l}\text { Age, sex, physical activity, smoking status, education level, BMI, } \\
\text { alcohol intake, total energy intake, intakes of saturated fatty acids, } \\
\text { trans fatty acids, fruit, vegetables, and dietary fiber }\end{array}$ \\
\hline Zhang 2018, USA [18] & $50-71$ & 16 & $14824 / 240,729$ & $\mathrm{M} / \mathrm{F}$ & 5 & $0.9(0.86-0.94)$ & 8 & $\begin{array}{c}\text { Age, BMI, race, education, marital status, smoking, alcohol, intake } \\
\text { of total energy, red meat, saturated fat, vegetables and fruits, } \\
\text { multi-vitamin use, aspirin use, history of diabetes, history of } \\
\text { hypertension, history of high cholesterol level }\end{array}$ \\
\hline Bellavia 2017, Sweden [23] & $45-83$ & 17 & $5039 / 72,522$ & $\mathrm{M} / \mathrm{F}$ & 5 & $\begin{array}{c}0.95 \\
(0.94-0.95)\end{array}$ & 9 & $\begin{array}{l}\text { BMI, total physical activity, smoking status and pack-years of } \\
\text { smoking, alcohol consumption, educational level (primary school, } \\
\text { secondary school or university), total energy intake, fruit } \\
\text { consumption, vegetable consumption, processed red meat } \\
\text { consumption and non-processed red meat consumption }\end{array}$ \\
\hline Nahab 2016, USA [24] & $\geq 40$ & 5.1 & $582 / 16,479$ & $\mathrm{M} / \mathrm{F}$ & 4 & $\begin{array}{c}1.46 \\
(0.87-2.45)\end{array}$ & 7 & $\begin{array}{l}\text { Age, race, region, sex, income, education, exercise, smoking status, } \\
\text { Mediterranean diet score, regular aspirin use, total energy intake } \\
\left(\mathrm{kcald}^{-1}\right) \text {, current use of hypertensive medication, diabetes status, } \\
\text { systolic blood pressure, BMI and dyslipidaemia }\end{array}$ \\
\hline
\end{tabular}


Table 1. Cont.

\begin{tabular}{|c|c|c|c|c|c|c|c|c|}
\hline $\begin{array}{l}\text { Author Name, Year, } \\
\text { Country }\end{array}$ & $\begin{array}{l}\text { Age } \\
\text { Range/Mean } \\
\text { Age (y) }\end{array}$ & $\begin{array}{l}\text { Follow-Up } \\
\text { Duration }\end{array}$ & $\begin{array}{l}\text { Number of } \\
\text { Cases/Size }\end{array}$ & Gender & Quantile & $\begin{array}{l}\text { Adjusted RR } \\
\quad(95 \% \mathrm{CI})\end{array}$ & $\begin{array}{l}\text { Quality } \\
\text { Score }\end{array}$ & Adjustments \\
\hline Owen 2016, Australia [25] & $\geq 25$ & 9.7 & $277 / 11,247$ & $\mathrm{M} / \mathrm{F}$ & 4 & $0.66(0.46-0.96)$ & 7 & $\begin{array}{c}\text { Age, previous CVD, education, exercise, diabetes, total dietary } \\
\text { energy and smoking }\end{array}$ \\
\hline Eguchi 2014, Japan [26] & $40-79$ & 19.3 & $2412 / 42,946$ & $\mathrm{M} / \mathrm{F}$ & 2 & $0.89(0.82-0.97)$ & 8 & $\begin{array}{l}\text { Age, body mass index, history of hypertension, history of diabetes, } \\
\text { education level, regular employment, perceived mental stress, and } \\
\quad 7 \text { health behaviors }\end{array}$ \\
\hline Takata 2013, China [27] & $40-74$ & 8.7 & $1789 / 134,296$ & $\mathrm{M} / \mathrm{F}$ & 5 & $\begin{array}{c}0.86 \\
(0.70-1.05)\end{array}$ & 6 & $\begin{array}{c}\text { Age at baseline, total energy intake, income, occupation, education, } \\
\text { comorbidity index, physical activity level, red meat intake, poultry } \\
\text { intake, total vegetable intake, total fruit intake, smoking history, } \\
\text { and alcohol consumption }\end{array}$ \\
\hline Tomasallo 2010, USA [28] & 45.8 & 12 & $44 / 1367$ & $\mathrm{M} / \mathrm{F}$ & 3 & $0.45(0.21-0.99)$ & 7 & Age, sex, body mass index, and income at study baseline \\
\hline Yamagishi 2008, Japan [29] & $40-79$ & 12.7 & $2045 / 57,972$ & $\mathrm{M} / \mathrm{F}$ & 5 & $0.82(0.71-0.95)$ & 7 & $\begin{array}{c}\text { Age, gender, history of hypertension and diabetes mellitus, } \\
\text { smoking status, alcohol consumption, body mass index, mental } \\
\text { stress, walking, sports, education levels, total energy, and dietary } \\
\text { intakes of cholesterol, saturated and n-6 polyunsaturated fatty } \\
\text { acids, vegetables, and fruit }\end{array}$ \\
\hline Folsom 2004, USA [30] & $55-69$ & 14 & $1589 / 41,836$ & $\mathrm{~F}$ & 5 & $0.95(0.78-1.15)$ & 7 & $\begin{array}{l}\text { Age, energy intake, educational level, physical activity level, alcohol } \\
\text { consumption, smoking status, pack-years of cigarette smoking, age at } \\
\text { first livebirth, estrogen use, vitamin use, body mass index, waist/hip } \\
\text { ratio, diabetes, hypertension, intake of whole grains, fruit and } \\
\text { vegetables, red meat, cholesterol, and saturated fat }\end{array}$ \\
\hline Gillum 2000, USA [31] & $25-74$ & 18.8 & $-/ 8825$ & $\mathrm{M} / \mathrm{F}$ & 4 & $1.01(0.81-1.25)$ & 9 & $\begin{array}{l}\text { Age, smoking, history of diabetes, education, high school graduate, } \\
\text { systolic blood pressure, serum cholesterol concentration, body mass } \\
\text { index, alcohol intake, and physical activity }\end{array}$ \\
\hline Albert 1998 [32] & $40-84$ & 11 & $548 / 20,551$ & M & 5 & $0.81(0.49-1.33)$ & 8 & $\begin{array}{l}\text { Age, aspirin and beta carotene treatment assignment, evidence of } \\
\text { cardiovascular disease, prior to 12-month questionnaire, body } \\
\text { mass index, smoking status, history of diabetes, history of } \\
\text { hypertension, history of hypercholesterolemia, alcohol } \\
\text { consumption, vigorous exercise, and vitamin E, vitamin C, and } \\
\text { multivitamin use }\end{array}$ \\
\hline Daviglus 1997 [33] & $40-55$ & 30 & $573 / 2107$ & M & 4 & $0.74(0.52-1.06)$ & 8 & $\begin{array}{c}\text { Age, education, religion, systolic pressure, serum cholesterol, } \\
\text { number of cigarettes smoked per day, body-mass index, presence } \\
\text { or absence of diabetes, presence or absence of electrocardiographic } \\
\text { abnormalities, daily intake of energy, cholesterol, saturated, } \\
\text { monounsaturated, and polyunsaturated fatty acids, total protein, } \\
\text { carbohydrate, alcohol, iron, thiamine, riboflavin, niacin, vitamin C, } \\
\text { beta carotene, and retinol }\end{array}$ \\
\hline
\end{tabular}


Table 2. General characteristics of the studies included in meta-analysis of marine n-3 PUFA intake and risk of CVD mortality.

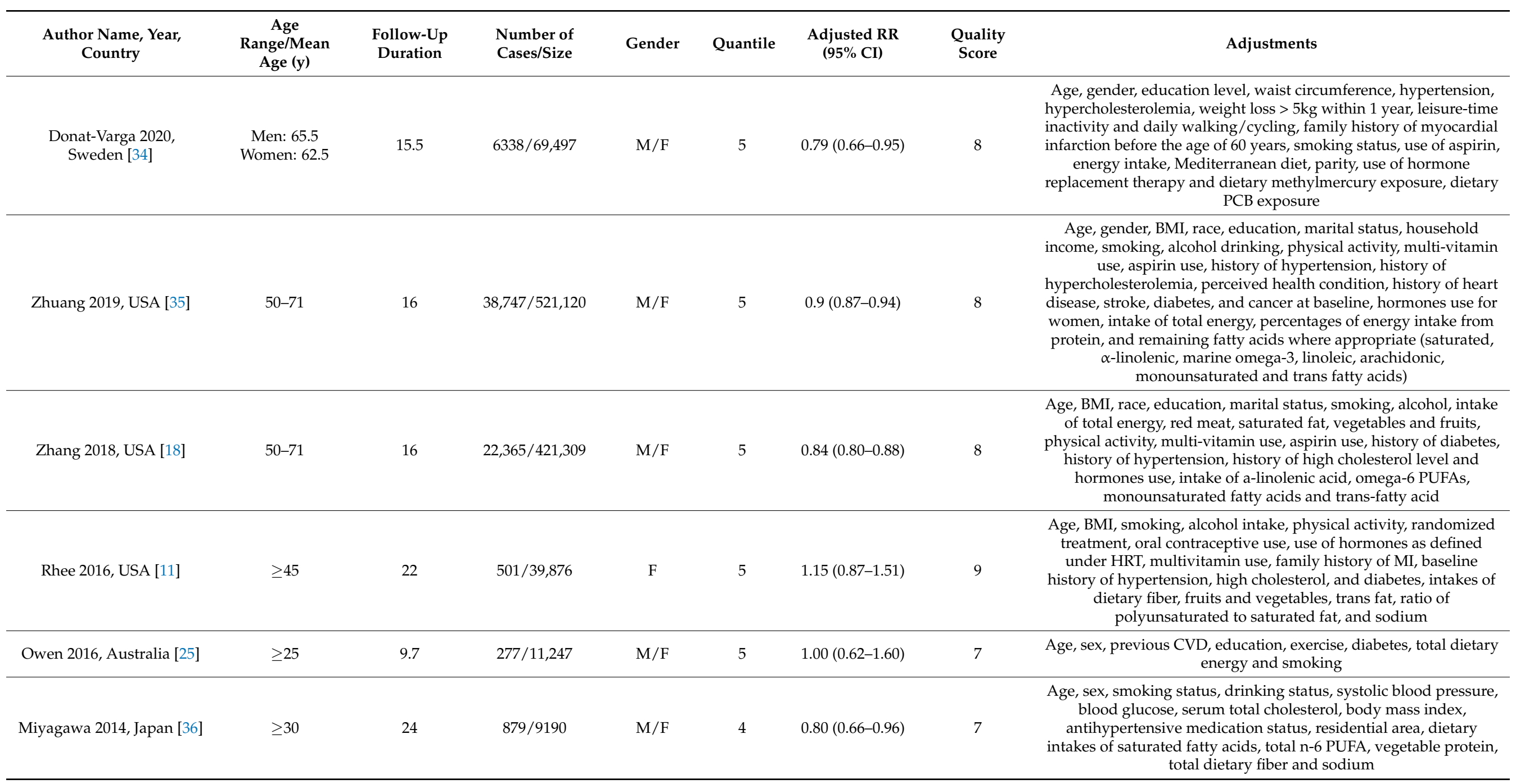


Table 2. Cont.

\begin{tabular}{|c|c|c|c|c|c|c|c|c|}
\hline $\begin{array}{c}\text { Author Name, Year, } \\
\text { Country }\end{array}$ & $\begin{array}{c}\text { Age } \\
\text { Range/Mean } \\
\text { Age (y) }\end{array}$ & $\begin{array}{l}\text { Follow-Up } \\
\text { Duration }\end{array}$ & $\begin{array}{l}\text { Number of } \\
\text { Cases/Size }\end{array}$ & Gender & Quantile & $\begin{array}{l}\text { Adjusted RR } \\
\text { (95\% CI) }\end{array}$ & $\begin{array}{l}\text { Quality } \\
\text { Score }\end{array}$ & Adjustments \\
\hline Bell 2014, USA [37] & $50-76$ & 5 & $769 / 70,495$ & $\mathrm{M} / \mathrm{F}$ & 4 & $0.87(0.68-1.10)$ & 6 & $\begin{array}{l}\text { Age, sex, raceethnicity, marital status, education, body mass index, } \\
\text { physical activity, smoking, alcohol intake, total energy intake, } \\
\text { vegetables intake, dietary intake of arachidonic acid, aspirin use, } \\
\text { use of non-aspirin nonsteroidal anti-inflammatory drugs, self-rated } \\
\text { health, sigmoidoscopy, mammogram, prostate-specific antigen test, } \\
\text { current use of cholesterol-lowering medication, history of } \\
\text { cardiovascular disease, family history of heart attack, current use of } \\
\text { blood pressure medication, percentage of calories derived from } \\
\text { trans-fat, percentage of calories derived from saturated fat, years of } \\
\text { estrogen therapy, and years of estrogen + progestin therapy etc. }\end{array}$ \\
\hline Koh 2013, Singapore [38] & $45-74$ & 14.8 & $4780 / 60,298$ & $\mathrm{M} / \mathrm{F}$ & 4 & $0.86(0.77-0.96)$ & 8 & $\begin{array}{l}\text { Age, sex, dialect, year of interview, educational level, body mass } \\
\text { index, physical activity, smoking status, alcohol use, baseline } \\
\text { history of self-reported diabetes, hypertension, coronary heart } \\
\text { disease, stroke, and total energy, adjusted for intakes of protein, } \\
\text { dietary fiber, monounsaturated fat, saturated fat, omega- } 6 \text { fatty } \\
\text { acids, and alternate omega-3 fatty acids }\end{array}$ \\
\hline Takata 2013, China [27] & $40-74$ & 8.7 & $1789 / 134,296$ & $\mathrm{M} / \mathrm{F}$ & 5 & $0.74(0.62-0.88)$ & 6 & $\begin{array}{l}\text { Age, total energy intake, income, occupation, education, } \\
\text { comorbidity index, physical activity level, red meat intake, poultry } \\
\text { intake, total vegetable intake, total fruit intake, smoking history, } \\
\text { and alcohol consumption (among men only) }\end{array}$ \\
\hline $\begin{array}{l}\text { Kamphuis 2006, The } \\
\text { Netherlands [39] }\end{array}$ & $70-79$ & 10 & $92 / 332$ & M & 3 & $0.88(0.51-1.5)$ & 8 & $\begin{array}{l}\text { Age, years of education, BMI, smoking, alcohol consumption, } \\
\text { systolic blood pressure, total and HDL-cholesterol concentrations, } \\
\text { physical activity, living alone, and energy intake }\end{array}$ \\
\hline
\end{tabular}

n-3 PUFA, n-3 polyunsaturated fatty acid; CVD, cardiovascular disease; PCB, polychlorinated biphenyl; BMI, body mass index; HRT, hormone replacement therapy; MI, myocardial infarction. 


\subsection{Fish Consumption and Cardiovascular Disease Mortality Risk}

Eighteen studies, involving 1,267,951 participants and 51,628 CVD deaths, investigated the association between the fish intake and the CVD mortality risk [13-18,23-33,40]. The pooled RR $(95 \% \mathrm{CI})$ was $0.91(0.85-0.98)$ for the highest versus the lowest fish consumption category $\left(\mathrm{I}^{2}=70.0 \%\right.$ ) (Figure 2$)$. Sensitivity analysis did not change the protective effects of fish on CVD mortality (Figure S1). Subgroup analysis suggested that there was a significant negative association between the fish intake and the CVD mortality risk among the subgroups with nine years or more follow-up duration (Table 3). No publication bias was found (Egger's test: $p=0.919$; funnel plot: Figure S2).

Figure $3 a$ showed the linear and non-linear dose-response analyses between the fish intake and the CVD mortality risk. Ten prospective cohort studies met the requirements for dose-response analysis $[13,15-18,23,27,29,33,40]$, and the curvilinear correlation presented a downward trend for the adjusted RR of CVD deaths with the increase of fish consumption from zero to $40 \mathrm{~g} / \mathrm{d}$ ( $p$ non-linearity $<0.001)$. The adjusted $\mathrm{RR}$ reached a steady value when fish consumption increased beyond $40 \mathrm{~g} / \mathrm{d}$. In the linear dose-response analysis, the summary RR (95\% CI) for a $20 \mathrm{~g} / \mathrm{d}$ increment was $0.96(0.94-0.99)$ for CVD mortality risk $(p$ trend $=0.002)$.

\begin{tabular}{|c|c|c|c|}
\hline $\begin{array}{l}\text { Study } \\
\text { ID }\end{array}$ & & $\mathrm{RR}(95 \% \mathrm{Cl})$ & $\begin{array}{l}\% \\
\text { Weight }\end{array}$ \\
\hline Mohan2021 & & $0.85(0.77,0.94)$ & 9.02 \\
\hline Kobayashi2019 & 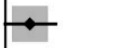 & $1.14(0.99,1.32)$ & 7.67 \\
\hline Kondo2019 & & $0.72(0.56,0.91)$ & 5.01 \\
\hline Van den brandt2019 & $\rightarrow$ & $1.45(1.20,1.74)$ & 6.44 \\
\hline Deng2018 & & $0.69(0.50,0.96)$ & 3.50 \\
\hline Hengeveld2018 & & $0.94(0.80,1.10)$ & 7.21 \\
\hline Zhang2018 & & $0.90(0.86,0.94)$ & 10.37 \\
\hline Bellavia2017 & & $0.95(0.76,1.19)$ & 5.44 \\
\hline Nahab2016 & 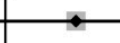 & $1.46(0.87,2.45)$ & 1.73 \\
\hline Owen2016 & & $0.66(0.46,0.96)$ & 2.96 \\
\hline Eguchi2014 & & $0.89(0.82,0.97)$ & 9.47 \\
\hline Takata2013 & & $0.86(0.70,1.05)$ & 5.98 \\
\hline Tomasallo2010 & & $0.45(0.21,0.99)$ & 0.85 \\
\hline Yamagishi2008 & & $0.82(0.71,0.95)$ & 7.62 \\
\hline Folsom2004 & & $0.95(0.78,1.15)$ & 6.21 \\
\hline Gillum2000 & - & $1.01(0.81,1.25)$ & 5.61 \\
\hline Albert1998 & & $0.81(0.49,1.33)$ & 1.84 \\
\hline Daviglus1997 & & $0.74(0.52,1.06)$ & 3.10 \\
\hline Overall $(\mathrm{I}$-squared $=70.0 \%, p=0.000 \%$ & & $0.91(0.85,0.98)$ & 100.00 \\
\hline NOTE: Weights are from random effects analysis & & & \\
\hline 0.21 & 1 & 4.76 & \\
\hline
\end{tabular}

Figure 2. Forest plot of the highest versus lowest fish intake category and CVD mortality risk. Plot demonstrates decreased risk of CVD mortality risk with fish intake by the random-effects model ( $R R=0.91 ; 95 \%$ CI, 0.85-0.98). CVD, cardiovascular disease; RR, relevant risk; CI, confidence intervals.

\subsection{Marine n-3 PUFA and Cardiovascular Disease Mortality Risk}

Ten eligible studies with 1,337,660 participants and 76,537 CVD deaths explored the association of marine n-3 PUFA intake with CVD mortality risk [11,18,25,27,34-39]. The pooled RR (95\% CI) for the highest versus the lowest marine n-3 PUFA consumption category was $0.87(0.85-0.89)$, with a low heterogeneity $\left(\mathrm{I}^{2}=37.8 \%\right)$ (Figure 4$)$. Sensitivity analysis suggested a great impact on one article with high quality (Figure S3) [35]. The negative association between marine n-3 PUFA and the risk of CVD mortality was altered 
from $0.87(0.85-0.89)$ to $0.84(0.81-0.87)$ by deleting this study. Subgroup analyses displayed a significant negative association among the Americas, and Asian and European countries compared with Oceania countries (Table 3). No publication bias was found (Egger's test: $p=0.722$; funnel plot: Figure S4). Figure 3b showed the linear and non-linear dose-response analysis between marine n-3 PUFA intake and CVD mortality risk. Eight prospective cohort studies met the requirements of dose-response analysis [18,25,27,34,36-39], and the curvilinear correlation presented a downward trend of CVD deaths with the increase of n-3 PUFA intake $(p$ non-linearity $<0.001)$. Linear dose-response analysis suggested that an increase of 80 milligrams of n-3 PUFA per day was associated with a $4 \%$ lower risk of CVD mortality (95\% CI: 0.94-0.98; $\left.p_{\text {trend }}<0.001\right)$.
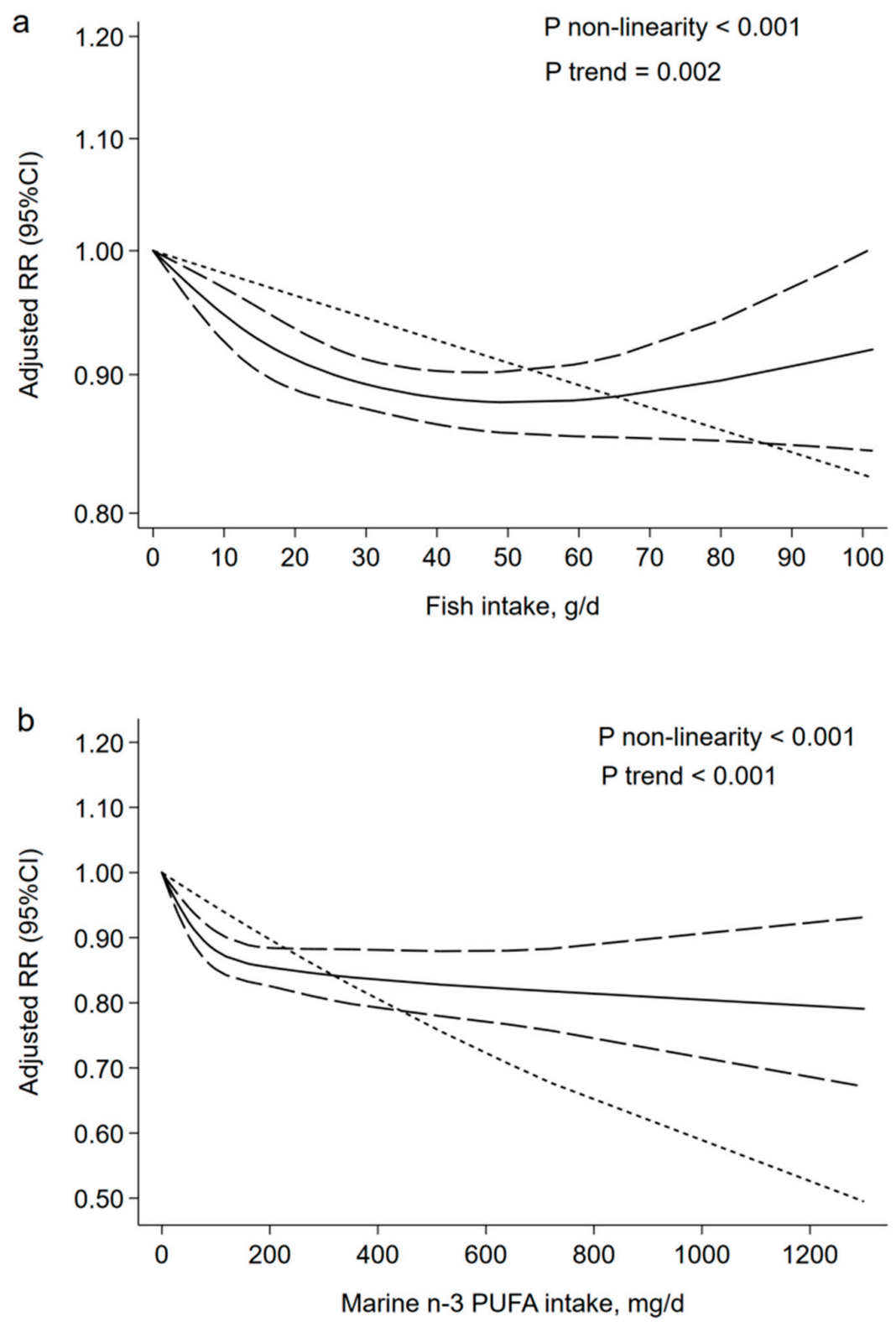

Figure 3. Dose-response association: (a) fish and CVD mortality $(n=10, p$ non-linearity $<0.001$; $p$ trend $=0.002)$; the risk of CVD mortality was decreased by $4 \%$ with an increase of $20 \mathrm{~g}$ of fish intake ( $R R=0.96 ; 95 \%$ CI: 0.94-0.99) per day. (b) marine n-3 PUFA and CVD mortality $(n=8$, $p$ non-linearity $<0.001 ; p$ trend $<0.001)$; the risk of CVD mortality was decreased by $4 \%$ with an increase of 80 milligrams of marine n-3 PUFA intake (RR $=0.96 ; 95 \%$ CI: 0.94-0.98) per day. CVD, cardiovascular disease; n-3 PUFA, n-3 polyunsaturated fatty acids; RR, relevant risk; CI, confidence intervals; $\mathrm{g} / \mathrm{d}$, grams per day; $\mathrm{mg} / \mathrm{d}$, milligrams per day. 


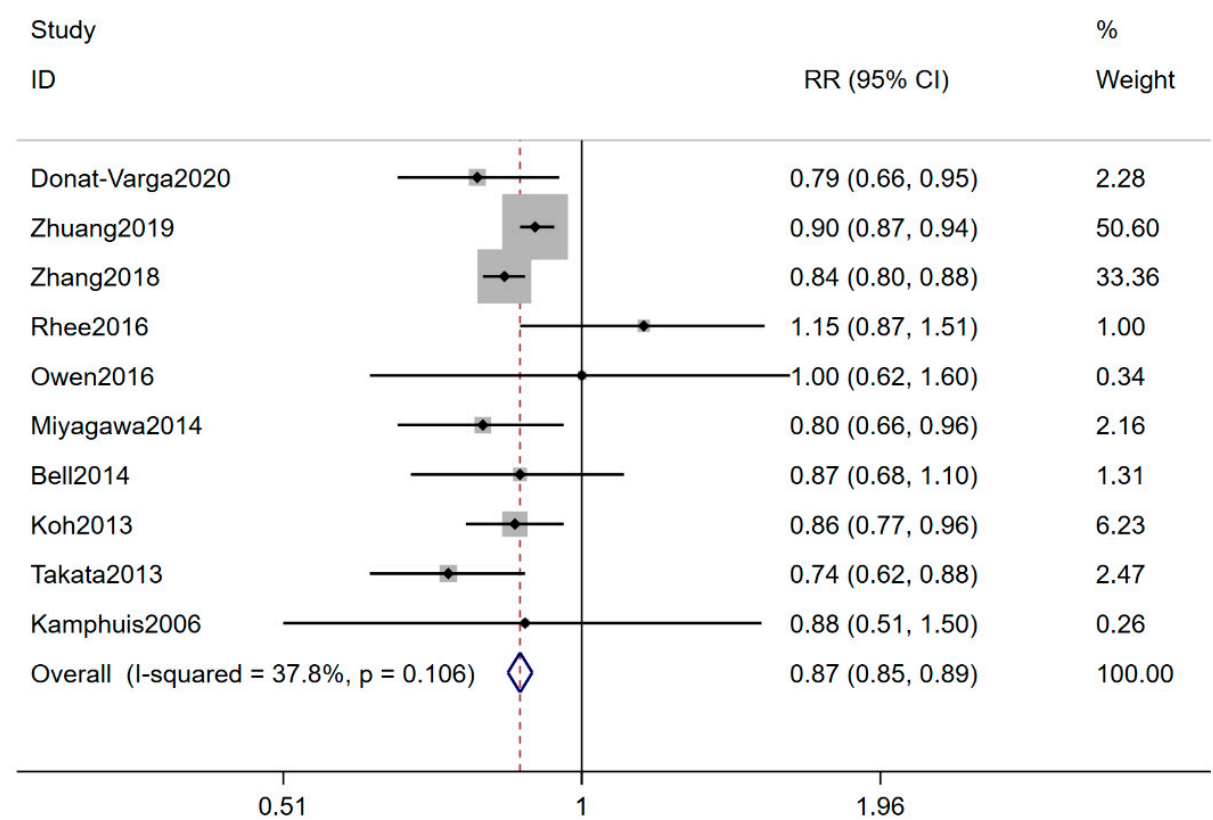

Figure 4. Forest plot of the highest versus lowest marine n-3 PUFA intake category and CVD mortality risk. Plot demonstrates decreased risk of CVD mortality risk with n-3 PUFA intake by the fixed-effects model ( $R R=0.87 ; 95 \%$ CI, 0.85-0.89). CVD, cardiovascular disease; n-3 PUFA, n-3 polyunsaturated fatty acids; RR, relevant risk; $\mathrm{CI}$, confidence intervals.

Table 3. Subgroup and meta-regression analyses for the association between fish, n-3 PUFA intake and CVD mortality.

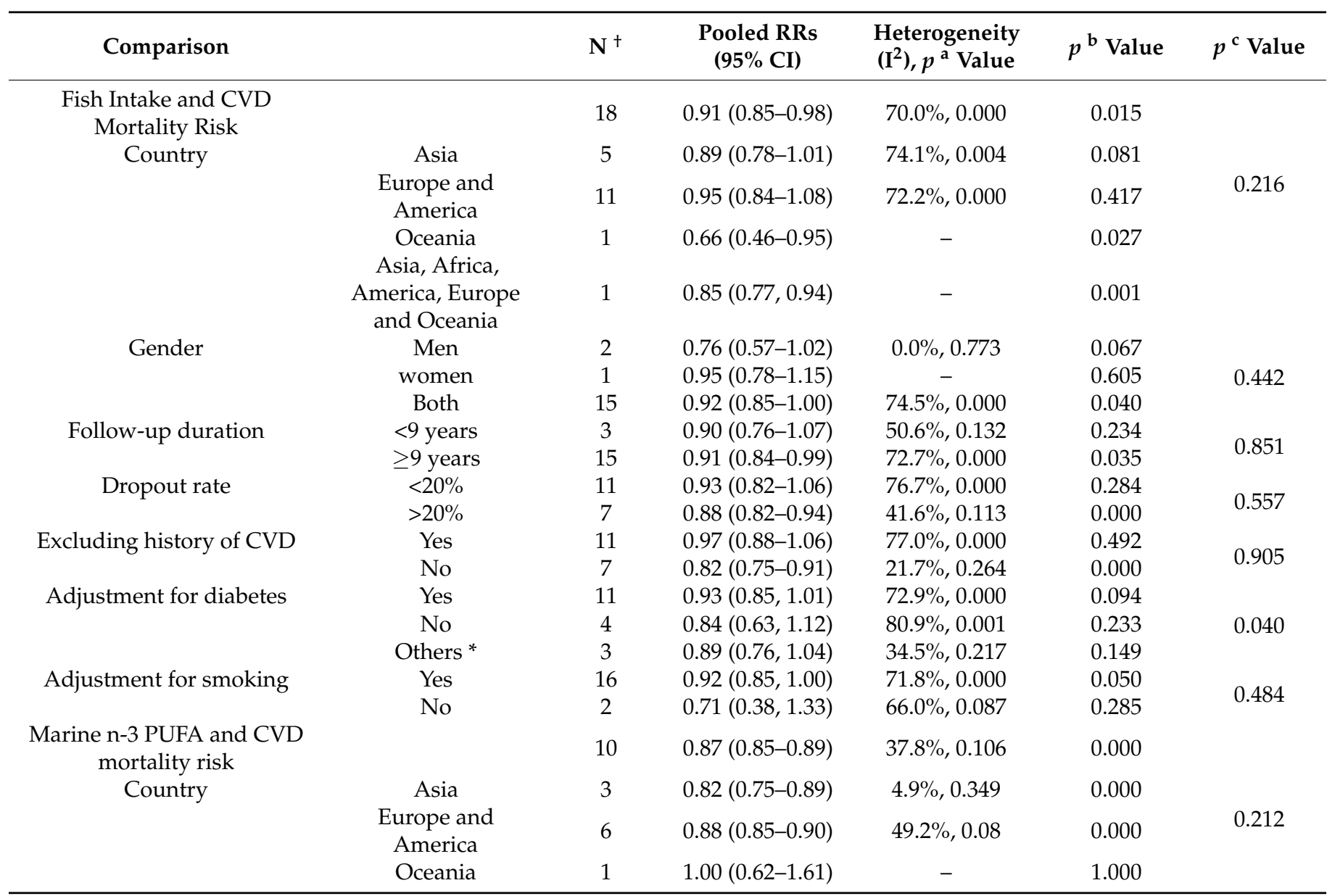


Table 3. Cont.

\begin{tabular}{|c|c|c|c|c|c|c|}
\hline Comparison & & $\mathbf{N}^{\dagger}$ & $\begin{array}{l}\text { Pooled RRs } \\
\text { (95\% CI) }\end{array}$ & $\begin{array}{l}\text { Heterogeneity } \\
\left(\mathrm{I}^{2}\right), p^{\text {a }} \text { Value }\end{array}$ & $p^{\mathrm{b}}$ Value & $p^{\mathrm{c}}$ Value \\
\hline \multirow[t]{3}{*}{ Gender } & Men & 1 & $0.88(0.51-1.51)$ & - & 0.642 & \multirow{3}{*}{0.182} \\
\hline & Women & 1 & $1.15(0.87-1.52)$ & - & 0.320 & \\
\hline & Both & 8 & $0.87(0.84-0.89)$ & $33.3 \%, 0.162$ & 0.000 & \\
\hline \multirow[t]{2}{*}{ Follow-up duration } & $<9$ years & 2 & $0.78(0.68-0.90)$ & $12.1 \%, 0.286$ & 0.001 & \multirow{2}{*}{0.192} \\
\hline & $\geq 9$ years & 8 & $0.87(0.85-0.90)$ & $37.0 \%, 0.134$ & 0.000 & \\
\hline \multirow[t]{2}{*}{ Dropout rate } & $<20 \%$ & 5 & $0.89(0.86-0.92)$ & $51.8 \%, 0.08$ & 0.000 & \multirow{2}{*}{0.114} \\
\hline & $>20 \%$ & 5 & $0.84(0.80-0.87)$ & $0.0 \%, 0.877$ & 0.000 & \\
\hline \multirow[t]{2}{*}{ Excluding history of CVD } & Yes & 5 & $0.84(0.81-0.88)$ & $29.9 \%, 0.222$ & 0.000 & \multirow{2}{*}{0.536} \\
\hline & No & 5 & $0.89(0.86-0.92)$ & $23.4 \%, 0.266$ & 0.000 & \\
\hline \multirow[t]{3}{*}{ Adjustment for diabetes } & Yes & 6 & $0.88(0.85,0.90)$ & $44.4 \%, 0.109$ & 0.000 & \multirow{3}{*}{0.060} \\
\hline & No & 3 & $0.77(0.68,0.88)$ & $0.0 \%, 0.745$ & 0.000 & \\
\hline & Others * & 1 & $0.79(0.66,0.95)$ & - & 0.011 & \\
\hline
\end{tabular}

$\mathrm{N}^{+}$Number of included studies; $p^{\text {a }}$ for heterogeneity; $p^{\mathrm{b}}$ for significance test; $p^{\mathrm{c}}$ for meta-regression analysis. Others * All patients were diabetic or not diabetic. n-3 PUFA, n-3 polyunsaturated fatty acid; CVD, cardiovascular disease.

\section{Discussion}

To our knowledge, the current work is the first meta-analysis of prospective observational studies for associating marine n-3 PUFA intake and CVD mortality risk. This study showed a significant inverse association between fish, marine n-3 PUFA intake and CVD mortality risk. Nonlinear dose-response relationship found that an increase of $20 \mathrm{~g}$ of fish intake or 80 milligrams of marine n-3 PUFA intake per day was associated with a $4 \%$ reduction in risk of CVD mortality.

In accordance with the previous study, the fish consumption was inversely associated with the CVD mortality risk in the current meta-analysis [12]. Bechthold et al.'s study also suggested a negative association between fish consumption and the risk of CVD [41]. Several studies showed no association between the fish intake and the risk of CVD [42,43]. Differences in preparation and type of fish might explain the observed difference. The progress of frying deteriorates oils through oxidation and hydrogenation, leading to an increase of trans fatty acids [44]. Trans fatty acids can aggravate inflammation and endothelial dysfunction, increasing the risk of CVD mortality [45]. Fish high in salt during cooking can increase the risk of CVD through increasing production of reactive oxygen species and oxidative stress, which contribute to impaired vascular function [46,47]. Fish can be divided into lean, medium-fatty or fatty fish with less than $2 \mathrm{~g}, 2-8 \mathrm{~g}$ and more than $8 \mathrm{~g}$ fat per $100 \mathrm{~g}$ in its body tissue [48]. Fatty fish diets significantly decreased the serum concentrations of triacylglycerol, apolipoprotein B, apolipoprotein CII and apolipoprotein CIII, which were known CVD risk markers [49]. Fishes also contain vitamin D, proteins, minerals and taurine which may decrease markers of inflammation and improve vascular function by increasing adiponectin levels [50]. In the subgroup of adjustment for diabetes, fish intake was associated with a reduction in the rate of major CVD mortality that approached significance $(R R=0.93 ; 95 \% C I$ : $0.85-1.01)$. Previous study has showed that supplementation of fish can decrease the CVD mortality risk in a diabetic population [51], the possible reason being that diabetes is a significant risk factor for CVD mortality [52]. EPA and DHA derived from fish can activate the G protein-coupled receptor 120 to reverse insulin resistance [53]. n-3 PUFA supplementation can protect against CVD in patients with diabetes [54].

In most studies where fish exits as an exposure variable, the observed benefits could often be attributed to the presence of fatty acids $[55,56]$. The long chain n-3 PUFA-namely, EPA and DHA - are naturally presented not only in fatty fish, but also in lean fish [57,58]. n3 PUFA supplementation can decrease the risk of CVD $[59,60]$. The plasma level of EPA and DHA in humans may increase after intake of fish to improve the composition of lipoprotein cholesterol as cardiovascular markers affecting the risk of CVD [61,62]. However, previous study showed that low-dose supplementation with EPA and DHA did not significantly 
reduce the rate of CVD events [63]. This possible reason may be related to presence or absence of a history of CVD. The patients in the trial were all myocardial infarction patients for 4 years before enrollment. $85 \%$ of the patients were receiving statins. Patients with CVD who are receiving good clinical treatment showed low risk of future cardiovascular events [64]. Therefore, we wanted to observe the effect of the long chain n-3 PUFA on CVD mortality through the long-term duration.

In this meta-analysis, we also found a negative association between the marine n-3 PUFA intake and the CVD mortality risk. In previous studies, the results were not consistent [65]. A randomized controlled trial (RCT) showed that n-3 PUFA supplementation $(866 \mathrm{mg} / \mathrm{d})$ for 3.5 years could reduce CVD mortality risk [66]. In contrast, the RCT with one-year n-3 PUFA supplementation $(850 \mathrm{mg} / \mathrm{d})$ suggested no association [67]. Although some randomized controlled trials (RCTs) had been published, the follow-up duration were short with most studies ranged from 1-5 years [66-68]. Hoverer, the cohort studies included in this meta-analysis have longer follow-up duration ranged from 5-29 years. CVD is a chronic disease with a long disease course. Longer follow-up duration was more in line with the nature of the CVD disease. The possible mechanisms were as follows. First, the plasma n-3 PUFA increased with the frequency and the amount of dietary n-3 PUFA intake $[69,70]$. A higher circulating n-3 PUFA may alter the cell membrane fluidity which modulates protein function and signaling. The dimerization and recruitment of toll-like receptor-4 may be disrupted to down-regulate the expression of nuclear factor-kappaB reducing the inflammatory responses, with the enrichment of n-3 PUFA [71]. Second, n-3 PUFA may inhibit oxidative stress through the nuclear factor E2-related factor 2/heme oxygenase-1 signaling pathway. 4-hydroxy-2E-hexenal, the product of n-3 PUFA peroxidation, will dissociate Nrf2 from Keap1 and react with the cysteine residues of Keap1 [72]. Then, Nrf2 can translocate into the nucleus and bind to antioxidant responsive element to increase the expression of HO-1 [73]. HO-1 is a representative antioxidant enzyme that can confer cytoprotection on a wide variety of cells against oxidative damage [72]. Third, n-3 PUFA may reduce the hepatic very low-density lipoprotein production rate to decrease the plasma triglyceride levels through affecting fatty acid desaturases, fatty acid elongases and peroxisomal $\beta$ - gene expression and fatty acid beta-oxidation [74,75]. In addition, long-chain n-3 PUFA may play an important role in improving the endothelial function, lowering circulating markers of endothelial dysfunction, such as E-selectin, vascular cell adhesion molecule-1 and intercellular adhesion molecule-1 [76-78].

The dose-response analysis showed that the risk of CVD mortality decreased with the increase of fish consumption from zero to $40 \mathrm{~g} / \mathrm{d}$. The adjusted RR reached a steady value when fish consumption increased beyond $40 \mathrm{~g} / \mathrm{d}$. Therefore, we believe that $40 \mathrm{~g} / \mathrm{d}$ is the ideal dose for preventing CVD mortality. This is basically consistent with the average fish intake of the population of Europe and America [23,30]. However, the average intake of people in Japan is higher than this level [13].

This study has several strengths. First, compared with the previous meta-analysis [12], this study included additional 11 studies to investigate the association between the fish consumption and the CVD mortality risk, which may have a higher statistical power. Second, this meta-analysis was first to investigate the association between marine n-3 PUFA intake and CVD mortality risk with prospective cohort studies. Third, most studies had a long follow-up duration (9-30 years). CVD is a chronic disease and longer followup duration can better explain the association between fish, marine n-3 PUFA and CVD mortality risk.

The limitations should be acknowledged. First, several deep-sea fishes may be contaminated, while only one article reported whether fishes had pollutants or not [28]. Second, it is hard to standardize the fish and marine n-3 PUFA consumption due to the details of measurement methods not being available. Thus, we chose RR $(95 \% \mathrm{CI})$ of the highest versus lowest fish and marine n-3 PUFA intake category and CVD mortality risk. 


\section{Conclusions}

This meta-analysis indicated that the fish and marine n-3 PUFA intake were inversely associated with reduced risk of CVD mortality. This finding has important public health implications in terms of the prevention of CVD mortality. Since the biomarkers of fish and n-3 PUFA within an individual are important for food absorption, further research needs to be performed in biomarkers.

Supplementary Materials: The following are available online at https:/ / www.mdpi.com/article/10 $.3390 /$ nu13072342/s1, Figure S1: Sensitivity analysis with respect to fish intake and CVD mortality risk. Figure S2: Funnel plot of the RR of 18 articles on fish intake and CVD mortality risk. Figure S3: Sensitivity analysis with respect to marine n-3 PUFA intake and CVD mortality risk. Figure S4: Funnel plot of the RR of 10 articles on marine n-3 PUFA intake and CVD mortality risk. Table S1: Quality assessment of studies investigating fish intake and CVD mortality risk. Table S2: Quality assessment of studies investigating marine n-3 PUFA intake and CVD mortality risk.

Author Contributions: L.J. and A.M. designed research; J.W., K.X., B.Z., L.X. and L.J. conducted research; L.J. analyzed data and wrote the paper. A.M. had primary responsibility for final content. All authors have read and agreed to the published version of the manuscript.

Funding: This research received no external funding.

Conflicts of Interest: The authors declare no conflict of interest.

\section{References}

1. Mortality, G.B.D.; Causes of Death, C. Global, regional, and national life expectancy, all-cause mortality, and cause-specific mortality for 249 causes of death, 1980-2015: A systematic analysis for the Global Burden of Disease Study 2015. Lancet 2016, 388, 1459-1544. [CrossRef]

2. Rosato, V.; Temple, N.J.; La Vecchia, C.; Castellan, G.; Tavani, A.; Guercio, V. Mediterranean diet and cardiovascular disease: A systematic review and meta-analysis of observational studies. Eur. J. Nutr. 2019, 58, 173-191. [CrossRef] [PubMed]

3. Wang, J.; Xiong, K.; Xu, L.; Zhang, C.; Zhao, S.; Liu, Y.; Ma, A. Dietary Intake of Vegetables and Cooking Oil Was Associated with Drug-Induced Liver Injury During Tuberculosis Treatment: A Preliminary Cohort Study. Front. Nutr. 2021, 8, 652311. [CrossRef] [PubMed]

4. Xiong, K.; Zhou, L.; Wang, J.; Ma, A.; Fang, D.; Xiong, L.; Sun, Q. Construction of food-grade pH-sensitive nanoparticles for delivering functional food ingredients. Trends Food Sci. Technol. 2020, 96, 102-113. [CrossRef]

5. Denissen, K.F.M.; Heil, S.G.; Eussen, S.; Heeskens, J.P.J.; Thijs, C.; Mommers, M.; Smits, L.J.M.; van Dongen, M.; Dagnelie, P.C. Intakes of Vitamin B-12 from Dairy Food, Meat, and Fish and Shellfish Are Independently and Positively Associated with Vitamin B-12 Biomarker Status in Pregnant Dutch Women. J. Nutr. 2019, 149, 131-138. [CrossRef]

6. Bergqvist, C.; Ezzedine, K. Vitamin D and the skin: What should a dermatologist know? G. Ital. Dermatol. Venereol. 2019, 154, 669-680. [CrossRef]

7. Hustad, K.S.; Rundblad, A.; Ottestad, I.; Christensen, J.J.; Holven, K.B.; Ulven, S.M. Comprehensive lipid and metabolite profiling in healthy adults with low and high consumption of fatty fish: A cross-sectional study. Br. J. Nutr. 2020, 1-23. [CrossRef]

8. Asher, A.; Tintle, N.L.; Myers, M.; Lockshon, L.; Bacareza, H.; Harris, W.S. Blood omega-3 fatty acids and death from COVID-19: A pilot study. Prostaglandins Leukot. Essent. Fat. Acids 2021, 166, 102250. [CrossRef]

9. O'Keefe, J.H., Jr.; Abuissa, H.; Sastre, A.; Steinhaus, D.M.; Harris, W.S. Effects of omega-3 fatty acids on resting heart rate, heart rate recovery after exercise, and heart rate variability in men with healed myocardial infarctions and depressed ejection fractions. Am. J. Cardiol. 2006, 97, 1127-1130. [CrossRef]

10. Jayedi, A.; Shab-Bidar, S. Fish Consumption and the Risk of Chronic Disease: An Umbrella Review of Meta-Analyses of Prospective Cohort Studies. Adv. Nutr. 2020. [CrossRef]

11. Rhee, J.J.; Kim, E.; Buring, J.E.; Kurth, T. Fish Consumption, Omega-3 Fatty Acids, and Risk of Cardiovascular Disease. Am. J. Prev. Med. 2017, 52, 10-19. [CrossRef] [PubMed]

12. Jayedi, A.; Shab-Bidar, S.; Eimeri, S.; Djafarian, K. Fish consumption and risk of all-cause and cardiovascular mortality: A dose-response meta-analysis of prospective observational studies. Public Health Nutr. 2018, 21, 1297-1306. [CrossRef] [PubMed]

13. Kobayashi, M.; Sasazuki, S.; Shimazu, T.; Sawada, N.; Yamaji, T.; Iwasaki, M.; Mizoue, T.; Tsugane, S. Association of dietary diversity with total mortality and major causes of mortality in the Japanese population: JPHC study. Eur. J. Clin. Nutr. 2020, 74, 54-66. [CrossRef] [PubMed]

14. Deng, A.; Pattanaik, S.; Bhattacharya, A.; Yin, J.; Ross, L.; Liu, C.; Zhang, J. Fish consumption is associated with a decreased risk of death among adults with diabetes: 18-year follow-up of a national cohort. Nutr. Metab. Cardiovasc. Dis. 2018, 28, 1012-1020. [CrossRef] 
15. Kondo, K.; Miura, K.; Tanaka-Mizuno, S.; Kadota, A.; Arima, H.; Okuda, N.; Fujiyoshi, A.; Miyagawa, N.; Yoshita, K.; Okamura, T.; et al. Cardiovascular Risk Assessment Chart by Dietary Factors in Japan-NIPPON DATA80. Circ. J. 2019, 83, 1254-1260. [CrossRef]

16. van den Brandt, P.A. Red meat, processed meat, and other dietary protein sources and risk of overall and cause-specific mortality in The Netherlands Cohort Study. Eur. J. Epidemiol. 2019, 34, 351-369. [CrossRef]

17. Hengeveld, L.M.; Praagman, J.; Beulens, J.W.J.; Brouwer, I.A.; van der Schouw, Y.T.; Sluijs, I. Fish consumption and risk of stroke, coronary heart disease, and cardiovascular mortality in a Dutch population with low fish intake. Eur. J. Clin. Nutr. 2018, 72, 942-950. [CrossRef] [PubMed]

18. Zhang, Y.; Zhuang, P.; He, W.; Chen, J.N.; Wang, W.Q.; Freedman, N.D.; Abnet, C.C.; Wang, J.B.; Jiao, J.J. Association of fish and long-chain omega-3 fatty acids intakes with total and cause-specific mortality: Prospective analysis of 421309 individuals. J. Intern. Med. 2018, 284, 399-417. [CrossRef]

19. Stang, A. Critical evaluation of the Newcastle-Ottawa scale for the assessment of the quality of nonrandomized studies in meta-analyses. Eur. J. Epidemiol. 2010, 25, 603-605. [CrossRef]

20. Orsini, N.; Bellocco, R.; Greenland, S. Generalized least squares for trend estimation of summarized dose-response data. STATA J. 2016, 6, 40-57. [CrossRef]

21. Greenland, S.; Longnecker, M.P. Methods for trend estimation from summarized dose-response data, with applications to meta-analysis. Am. J. Epidemiol. 1992, 135, 1301-1309. [CrossRef]

22. Wang, X.; Ouyang, Y.; Liu, J.; Zhu, M.; Zhao, G.; Bao, W.; Hu, F.B. Fruit and vegetable consumption and mortality from all causes, cardiovascular disease, and cancer: Systematic review and dose-response meta-analysis of prospective cohort studies. BMJ 2014, 349, g4490. [CrossRef]

23. Bellavia, A.; Larsson, S.C.; Wolk, A. Fish consumption and all-cause mortality in a cohort of Swedish men and women. J. Intern. Med. 2017, 281, 86-95. [CrossRef]

24. Nahab, F.; Pearson, K.; Frankel, M.R.; Ard, J.; Safford, M.M.; Kleindorfer, D.; Howard, V.J.; Judd, S. Dietary fried fish intake increases risk of CVD: The REasons for Geographic and Racial Differences in Stroke (REGARDS) study. Public Health Nutr. 2016, 19, 3327-3336. [CrossRef]

25. Owen, A.J.; Magliano, D.J.; O’Dea, K.; Barr, E.L.; Shaw, J.E. Polyunsaturated fatty acid intake and risk of cardiovascular mortality in a low fish-consuming population: A prospective cohort analysis. Eur. J. Nutr. 2016, 55, 1605-1613. [CrossRef]

26. Eguchi, E.; Iso, H.; Tanabe, N.; Yatsuya, H.; Tamakoshi, A. Is the association between healthy lifestyle behaviors and cardiovascular mortality modified by overweight status? The Japan Collaborative Cohort Study. Prev. Med. 2014, 62, 142-147. [CrossRef]

27. Takata, Y.; Zhang, X.; Li, H.; Gao, Y.T.; Yang, G.; Gao, J.; Cai, H.; Xiang, Y.B.; Zheng, W.; Shu, X.O. Fish intake and risks of total and cause-specific mortality in 2 population-based cohort studies of 134,296 men and women. Am. J. Epidemiol. 2013, $178,46-57$. [CrossRef]

28. Tomasallo, C.; Anderson, H.; Haughwout, M.; Imm, P.; Knobeloch, L. Mortality among frequent consumers of Great Lakes sport fish. Environ. Res. 2010, 110, 62-69. [CrossRef] [PubMed]

29. Yamagishi, K.; Iso, H.; Date, C.; Fukui, M.; Wakai, K.; Kikuchi, S.; Inaba, Y.; Tanabe, N.; Tamakoshi, A.; Grp, J.S. Fish, omega-3 polyunsaturated fatty acids, and mortality from cardiovascular diseases in a nationwide community-based cohort of Japanese men and women-The JACC (Japan Collaborative Cohort Study for Evaluation of Cancer Risk) study. J. Am. Coll. Cardiol. 2008, 52, 988-996. [CrossRef]

30. Folsom, A.R.; Demissie, Z. Fish intake, marine omega-3 fatty acids, and mortality in a cohort of postmenopausal women. Am. J. Epidemiol. 2004, 160, 1005-1010. [CrossRef]

31. Gillum, R.F.; Mussolino, M.; Madans, J.H. The relation between fish consumption, death from all causes, and incidence of coronary heart disease. the NHANES I Epidemiologic Follow-up Study. J. Clin. Epidemiol. 2000, 53, 237-244. [CrossRef]

32. Albert, C.M.; Hennekens, C.H.; O’Donnell, C.J.; Ajani, U.A.; Carey, V.J.; Willett, W.C.; Ruskin, J.N.; Manson, J.E. Fish consumption and risk of sudden cardiac death. J. Am. Med. Assoc. 1998, 279, 23-28. [CrossRef]

33. Daviglus, M.L.; Stamler, J.; Orencia, A.J.; Dyer, A.R.; Liu, K.; Greenland, P.; Walsh, M.K.; Morris, D.; Shekelle, R.B. Fish consumption and the 30-year risk of fatal myocardial infarction. N. Engl. J. Med. 1997, 336, 1046-1053. [CrossRef]

34. Donat-Vargas, C.; Bellavia, A.; Berglund, M.; Glynn, A.; Wolk, A.; Akesson, A. Cardiovascular and cancer mortality in relation to dietary polychlorinated biphenyls and marine polyunsaturated fatty acids: A nutritional-toxicological aspect of fish consumption. J. Intern. Med. 2020, 287, 197-209. [CrossRef]

35. Zhuang, P.; Zhang, Y.; He, W.; Chen, X.; Chen, J.; He, L.; Mao, L.; Wu, F.; Jiao, J. Dietary Fats in Relation to Total and Cause-Specific Mortality in a Prospective Cohort of 521120 Individuals with 16 Years of Follow-Up. Circ. Res. 2019, 124, 757-768. [CrossRef]

36. Miyagawa, N.; Miura, K.; Okuda, N.; Kadowaki, T.; Takashima, N.; Nagasawa, S.Y.; Nakamura, Y.; Matsumura, Y.; Hozawa, A.; Fujiyoshi, A.; et al. Long-chain n-3 polyunsaturated fatty acids intake and cardiovascular disease mortality risk in Japanese: A 24-year follow-up of NIPPON DATA80. Atherosclerosis 2014, 232, 384-389. [CrossRef] [PubMed]

37. Bell, G.A.; Kantor, E.D.; Lampe, J.W.; Kristal, A.R.; Heckbert, S.R.; White, E. Intake of long-chain omega-3 fatty acids from diet and supplements in relation to mortality. Am. J. Epidemiol. 2014, 179, 710-720. [CrossRef] [PubMed]

38. Koh, A.S.; Pan, A.; Wang, R.; Odegaard, A.O.; Pereira, M.A.; Yuan, J.M.; Koh, W.P. The association between dietary omega-3 fatty acids and cardiovascular death: The Singapore Chinese Health Study. Eur. J. Prev. Cardiol. 2015, 22, 364-372. [CrossRef] [PubMed] 
39. Kamphuis, M.H.; Geerlings, M.I.; Tijhuis, M.A.; Kalmijn, S.; Grobbee, D.E.; Kromhout, D. Depression and cardiovascular mortality: A role for $\mathrm{n}-3$ fatty acids? Am. J. Clin. Nutr. 2006, 84, 1513-1517. [CrossRef]

40. Mohan, D.; Mente, A.; Dehghan, M.; Rangarajan, S.; O’Donnell, M.; Hu, W.; Dagenais, G.; Wielgosz, A.; Lear, S.; Wei, L.; et al. Associations of Fish Consumption with Risk of Cardiovascular Disease and Mortality Among Individuals with or Without Vascular Disease From 58 Countries. JAMA Intern. Med. 2021, 181, 631-649. [CrossRef]

41. Bechthold, A.; Boeing, H.; Schwedhelm, C.; Hoffmann, G.; Knuppel, S.; Iqbal, K.; De Henauw, S.; Michels, N.; Devleesschauwer, B.; Schlesinger, S.; et al. Food groups and risk of coronary heart disease, stroke and heart failure: A systematic review and dose-response meta-analysis of prospective studies. Crit. Rev. Food Sci. Nutr. 2019, 59, 1071-1090. [CrossRef]

42. Kuhn, T.; Teucher, B.; Kaaks, R.; Boeing, H.; Weikert, C.; Buijsse, B. Fish consumption and the risk of myocardial infarction and stroke in the German arm of the European Prospective Investigation into Cancer and Nutrition (EPIC-Germany). Br. J. Nutr. 2013, 110, 1118-1125. [CrossRef]

43. Myint, P.K.; Welch, A.A.; Bingham, S.A.; Luben, R.N.; Wareham, N.J.; Day, N.E.; Khaw, K.T. Habitual fish consumption and risk of incident stroke: The European Prospective Investigation into Cancer (EPIC)-Norfolk prospective population study. Public Health Nutr. 2006, 9, 882-888. [CrossRef]

44. Sun, Y.; Liu, B.; Snetselaar, L.G.; Robinson, J.G.; Wallace, R.B.; Peterson, L.L.; Bao, W. Association of fried food consumption with all cause, cardiovascular, and cancer mortality: Prospective cohort study. BMJ 2019, 364. [CrossRef] [PubMed]

45. Valenzuela, C.A.; Baker, E.J.; Miles, E.A.; Calder, P.C. Eighteencarbon trans fatty acids and inflammation in the context of atherosclerosis. Prog. Lipid Res. 2019, 76, 101009. [CrossRef]

46. He, F.J.; MacGregor, G.A. Role of salt intake in prevention of cardiovascular disease: Controversies and challenges. Nat. Rev. Cardiol. 2018, 15, 371-377. [CrossRef] [PubMed]

47. Lastra, G.; Dhuper, S.; Johnson, M.S.; Sowers, J.R. Salt, aldosterone, and insulin resistance: Impact on the cardiovascular system. Nat. Rev. Cardiol. 2010, 7, 577-584. [CrossRef]

48. VKM. Benefit-Risk Assessment of Fish and Fish Products in the Norwegian Diet-An Update. Scientific Opinion of the Scientific Steering Committee. VKM Report 15. Oslo, Norway, 2014; 293p, ISBN 978-82-8259-159-1. Available online: www.vkm.no (accessed on 25 April 2021).

49. Zhang, J.; Wang, C.; Li, L.; Man, Q.; Meng, L.; Song, P.; Froyland, L.; Du, Z.Y. Dietary inclusion of salmon, herring and pompano as oily fish reduces CVD risk markers in dyslipidaemic middle-aged and elderly Chinese women. Br. J. Nutr. 2012, 108, 1455-1465. [CrossRef]

50. Torris, C.; Smastuen, M.C.; Molin, M. Nutrients in Fish and Possible Associations with Cardiovascular Disease Risk Factors in Metabolic Syndrome. Nutrients 2018, 10, 952. [CrossRef]

51. Hu, F.B.; Cho, E.; Rexrode, K.M.; Albert, C.M.; Manson, J.E. Fish and long-chain omega-3 fatty acid intake and risk of coronary heart disease and total mortality in diabetic women. Circulation 2003, 107, 1852-1857. [CrossRef]

52. Wang, H.; Shara, N.M.; Lee, E.T.; Devereux, R.; Calhoun, D.; de Simone, G.; Umans, J.G.; Howard, B.V. Hemoglobin A1c, fasting glucose, and cardiovascular risk in a population with high prevalence of diabetes: The strong heart study. Diabetes Care 2011, 34, 1952-1958. [CrossRef]

53. Oh, D.Y.; Talukdar, S.; Bae, E.J.; Imamura, T.; Morinaga, H.; Fan, W.; Li, P.; Lu, W.J.; Watkins, S.M.; Olefsky, J.M. GPR120 is an omega-3 fatty acid receptor mediating potent anti-inflammatory and insulin-sensitizing effects. Cell 2010, 142, 687-698. [CrossRef]

54. Kromhout, D.; Geleijnse, J.M.; de Goede, J.; Oude Griep, L.M.; Mulder, B.J.; de Boer, M.J.; Deckers, J.W.; Boersma, E.; Zock, P.L.; Giltay, E.J. n-3 fatty acids, ventricular arrhythmia-related events, and fatal myocardial infarction in postmyocardial infarction patients with diabetes. Diabetes Care 2011, 34, 2515-2520. [CrossRef]

55. Bernasconi, A.A.; Lavie, C.J.; Milani, R.V.; Laukkanen, J.A. Omega-3 Benefits Remain Strong Post-STRENGTH. Mayo Clin. Proc. 2021, 96, 1371-1372. [CrossRef] [PubMed]

56. Gammelmark, A.; Nielsen, M.S.; Bork, C.S.; Lundbye-Christensen, S.; Tjonneland, A.; Overvad, K.; Schmidt, E.B. Association of fish consumption and dietary intake of marine n-3 PUFA with myocardial infarction in a prospective Danish cohort study. Br. J. Nutr. 2016, 116, 167-177. [CrossRef] [PubMed]

57. Torris, C.; Molin, M.; Smastuen, M.C. Lean Fish Consumption Is Associated with Beneficial Changes in the Metabolic Syndrome Components: A 13-Year Follow-Up Study from the Norwegian Tromso Study. Nutrients 2017, 9, 247. [CrossRef]

58. Jakobsen, M.U.; Due, K.M.; Dethlefsen, C.; Halkjaer, J.; Holst, C.; Forouhi, N.G.; Tjonneland, A.; Boeing, H.; Buijsse, B.; Palli, D.; et al. Fish consumption does not prevent increase in waist circumference in European women and men. Br. J. Nutr. 2012, 108, 924-931. [CrossRef]

59. Bernasconi, A.A.; Wiest, M.M.; Lavie, C.J.; Milani, R.V.; Laukkanen, J.A. Effect of Omega-3 Dosage on Cardiovascular Outcomes: An Updated Meta-Analysis and Meta-Regression of Interventional Trials. Mayo Clin. Proc. 2021, 96, 304-313. [CrossRef]

60. Okada, L.; Oliveira, C.P.; Stefano, J.T.; Nogueira, M.A.; Silva, I.; Cordeiro, F.B.; Alves, V.A.F.; Torrinhas, R.S.; Carrilho, F.J.; Puri, P.; et al. Omega-3 PUFA modulate lipogenesis, ER stress, and mitochondrial dysfunction markers in NASH-Proteomic and lipidomic insight. Clin. Nutr. 2018, 37, 1474-1484. [CrossRef]

61. Harris, W.S.; Tintle, N.L.; Imamura, F.; Qian, F.; Korat, A.V.A.; Marklund, M.; Djousse, L.; Bassett, J.K.; Carmichael, P.H.; Chen, Y.Y.; et al. Blood n-3 fatty acid levels and total and cause-specific mortality from 17 prospective studies. Nat. Commun 2021, 12, 2329. [CrossRef]

62. Rundblad, A.; Holven, K.B.; Bruheim, I.; Myhrstad, M.C.; Ulven, S.M. Effects of krill oil and lean and fatty fish on cardiovascular risk markers: A randomised controlled trial. J. Nutr. Sci. 2018, 7, e3. [CrossRef] 
63. Kromhout, D.; Giltay, E.J.; Geleijnse, J.M.; Alpha Omega Trial, G. n-3 fatty acids and cardiovascular events after myocardial infarction. N. Engl. J. Med. 2010, 363, 2015-2026. [CrossRef]

64. Roger, V.L.; Weston, S.A.; Gerber, Y.; Killian, J.M.; Dunlay, S.M.; Jaffe, A.S.; Bell, M.R.; Kors, J.; Yawn, B.P.; Jacobsen, S.J. Trends in incidence, severity, and outcome of hospitalized myocardial infarction. Circulation 2010, 121, 863-869. [CrossRef]

65. Elagizi, A.; Lavie, C.J.; O'Keefe, E.; Marshall, K.; O'Keefe, J.H.; Milani, R.V. An Update on Omega-3 Polyunsaturated Fatty Acids and Cardiovascular Health. Nutrients 2021, 13, 204. [CrossRef] [PubMed]

66. Dietary supplementation with n-3 polyunsaturated fatty acids and vitamin E after myocardial infarction: Results of the GISSIPrevenzione trial. Gruppo Italiano per lo Studio della Sopravvivenza nell'Infarto miocardico. Lancet 1999, 354, 447-455. [CrossRef]

67. Rauch, B.; Schiele, R.; Schneider, S.; Diller, F.; Victor, N.; Gohlke, H.; Gottwik, M.; Steinbeck, G.; Del Castillo, U.; Sack, R.; et al. OMEGA, a randomized, placebo-controlled trial to test the effect of highly purified omega-3 fatty acids on top of modern guideline-adjusted therapy after myocardial infarction. Circulation 2010, 122, 2152-2159. [CrossRef] [PubMed]

68. Einvik, G.; Klemsdal, T.O.; Sandvik, L.; Hjerkinn, E.M. A randomized clinical trial on n-3 polyunsaturated fatty acids supplementation and all-cause mortality in elderly men at high cardiovascular risk. Eur. J. Cardiovasc. Prev. Rehabil. 2010, 17, 588-592. [CrossRef]

69. Samieri, C.; Lorrain, S.; Buaud, B.; Vaysse, C.; Berr, C.; Peuchant, E.; Cunnane, S.C.; Barberger-Gateau, P. Relationship between diet and plasma long-chain n-3 PUFAs in older people: Impact of apolipoprotein E genotype. J. Lipid Res. 2013, 54, $2559-2567$. [CrossRef]

70. Hautero, U.; Poussa, T.; Laitinen, K. Simple dietary criteria to improve serum n-3 fatty acid levels of mothers and their infants. Public Health Nutr. 2017, 20, 534-541. [CrossRef]

71. Mozaffarian, D.; Wu, J.H. Omega-3 fatty acids and cardiovascular disease: Effects on risk factors, molecular pathways, and clinical events. J. Am. Coll. Cardiol. 2011, 58, 2047-2067. [CrossRef]

72. Bang, H.Y.; Park, S.A.; Saeidi, S.; Na, H.K.; Surh, Y.J. Docosahexaenoic Acid Induces Expression of Heme Oxygenase-1 and NAD(P)H:quinone Oxidoreductase through Activation of Nrf2 in Human Mammary Epithelial Cells. Molecules 2017, $22,969$. [CrossRef] [PubMed]

73. Zhu, W.; Ding, Y.; Kong, W.; Li, T.; Chen, H. Docosahexaenoic Acid (DHA) Provides Neuroprotection in Traumatic Brain Injury Models via Activating Nrf2-ARE Signaling. Inflammation 2018, 41, 1182-1193. [CrossRef] [PubMed]

74. Clarke, S.D. Polyunsaturated fatty acid regulation of gene transcription: A molecular mechanism to improve the metabolic syndrome. J. Nutr. 2001, 131, 1129-1132. [CrossRef]

75. Jump, D.B. Fatty acid regulation of hepatic lipid metabolism. Curr. Opin. Clin. Nutr. Metab. Care 2011, 14, 115-120. [CrossRef] [PubMed]

76. de Roos, B.; Mavrommatis, Y.; Brouwer, I.A. Long-chain n-3 polyunsaturated fatty acids: New insights into mechanisms relating to inflammation and coronary heart disease. Br. J. Pharmacol. 2009, 158, 413-428. [CrossRef] [PubMed]

77. Egert, S.; Stehle, P. Impact of n-3 fatty acids on endothelial function: Results from human interventions studies. Curr. Opin. Clin. Nutr. Metab. Care 2011, 14, 121-131. [CrossRef]

78. Felau, S.M.; Sales, L.P.; Solis, M.Y.; Hayashi, A.P.; Roschel, H.; Sa-Pinto, A.L.; Andrade, D.C.O.; Katayama, K.Y.; Irigoyen, M.C.; Consolim-Colombo, F.; et al. Omega-3 Fatty Acid Supplementation Improves Endothelial Function in Primary Antiphospholipid Syndrome: A Small-Scale Randomized Double-Blind Placebo-Controlled Trial. Front. Immunol 2018, 9, 336. [CrossRef] 